\title{
Intraretinal hemorrhage associated with visceral leishmaniasis
}

\section{Hemorragia intrarretiniana associada à leishmaniose visceral}

Ricardo Evangelista Marrocos de Aragão¹, leda Maria A. Barreira ${ }^{1}$, Leidiane Adriano Pereira ${ }^{1}$, Barbara Lorena A. Arrais $^{1}$, Francisco Holanda Oliveira Neto ${ }^{1}$, Everton Fernandes Vieira de Almeida1, André Jucá Machado

\begin{abstract}
Visceral Leishmaniasis, also know as Kala-azar, is a parasitic tropical disease caused by protozoa of the genus Leishmania donovani. It is an endemic disease in many countries. It affects approximately 1,5 million people every year, and when associated with mal-nutrition and co-infection it may be fatal. Fever, hepatosplenomegaly, and pancytopenia is its typical clinical picture. Ocular manifestations of Kalaazar are relatively rare and can affect either anterior or posterior segment of the eye. We report a patient with kala-azar presenting intraretinal hemorrhages that regress completely after the successful treatment for visceral leishmaniasis.
\end{abstract}

Keywords: Leishmaniasis, visceral; Retina; Macula lutea; Pancytopenia; Retinal hemorrhage

\section{RESUMO}

Leishmaniose visceral, também conhecida como calazar é uma doença tropical parasitária, causada pelo protozoário do gênero Leishmania donovan uma doença endêmica em muitos países. Afeta aproximadamente 1,5 milhões de pessoas durante todo ano e quando associada à desnutrição e coinfecção pode ser fatal. Febre, hepatoesplenomegalia e pancitopenia e o quadro típico. Manifestações oculares são raras e podem afetar tanto o segmento anterior como o posterior do olho. Relatamos o caso de um paciente com calazar e hemorragia intrarretiniana que regrediu após tratamento para leishmaniose visceral.

Descritores: Leishmaniose visceral; Retina; Mácula lútea; Pancitopenia; Hemorragia retiniana

\footnotetext{
${ }^{1}$ Department of Ophthalmology, Faculdade de Medicina da Universidade Federal do Ceará - Fortaleza (CE), Brazil.

This work was carried out at department of Ophthalmology, Faculdade de Medicina, Universidade Federal do Ceará - Fortaleza (CE), Brazil. The authors declare no conflict of interest.

Recebido para publicação em 26/04/2015 - Aceito para publicação em 26/05/2015
} 


\section{INTRODUCTION}

$\mathbf{L}$ eishmaniasis is a tropical disease that primarily affects either the mononuclear-phagocytic system (visceral leishmanniasis) or the skin (cutaneous leishmaniasis) ${ }^{(1)}$. Visceral leishmaniasis is also know as kala-azar, a Hindi word that means "black sickness". Others terms are less frequently used, such as Burdwan fever, Dumdum fever, and Shahi's disease $^{(2)}$. Leishmaniais is a parasitic disease, which is widespread in over 88 countries in the world. It is endemic in Asia, Africa, and South America, and in Europe in some areas of the Mediterranean basin. Approximately 1,5 million new cases occur each year ${ }^{(3)}$. It is a chronic disease caused by protozoa of the genus Leishmania donovani complex, and is transmitted through the bite of the sandfly (phlebotomus). It is characterized by irregular fever, hepatosplenomegaly, weight loss, hypergammaglobulinemia, and pancytopenia ${ }^{(1)}$.

Until 1978, there were few reports on ocular involvement in the systemic disease from Africa and Unites States. Since then, there have been an increased number of report cases of ocular leishmaniasis in the form of cutaneuos eyelid involvement, as well blepharoconjunctivitis, ulcerative conjunctivitis, nodular episcleritis, keratitis, anterior uveitis, dacryocistitis, retinal hemorrhages and even a bilateral panuveitis complicated by retinal detachment and proliferative vitreoretinopathy ${ }^{(4,5)}$.

\section{Case Report}

A 48-year-old man, who resided in a rural area of northeast Brazil, was hospitalized with malaise, fever, anorexia, weight loss, hepatosplenomegaly and pancitopenia. The case was suspect of visceral leishmaniasis and the bone marrow tap revealed pancytopenia. The treatment was started with lipossomal anfotericin-B. The diagnosis of visceral leishmaniasis was confirmed later by testing serum antibody to the leishmanial antigen K39. Shortly after hospitalization, the patient experienced a sudden of visual acuity in his left eye. Best-corrected visual acuity (BCVA) was 20/20 OD, and OS 20/40. Indirect ophthalmoscopy reveled three retinal hemorrhages, one of which was in the fovea; a central scotoma was seen in the campimetry of the left eye (figures 1,2). One month later, BCVA in the left eye had improved to 20/20 with no residual scotoma. Clinically, the patient was asymptomatic with complete resolution of hepatosplenomegaly and normalization of blood counts.

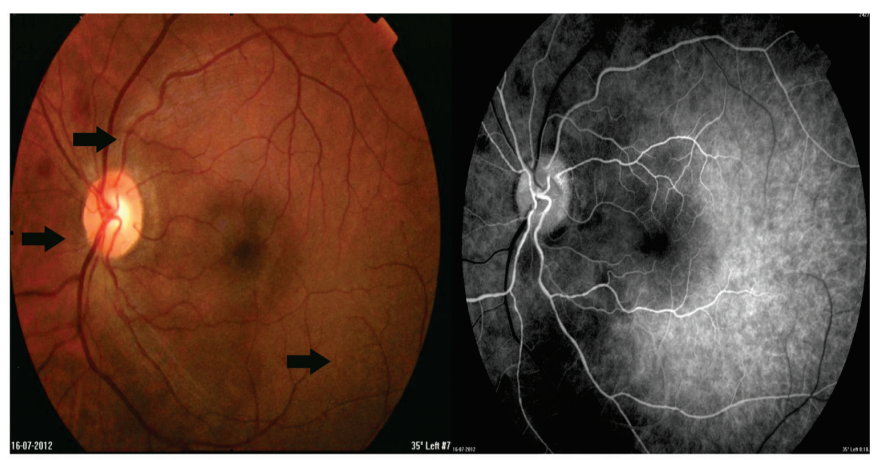

Figure 1: Fundus photography and corresponding fluorescein angiogram showing intraretinal hemorrhages (arrows) in the left eye
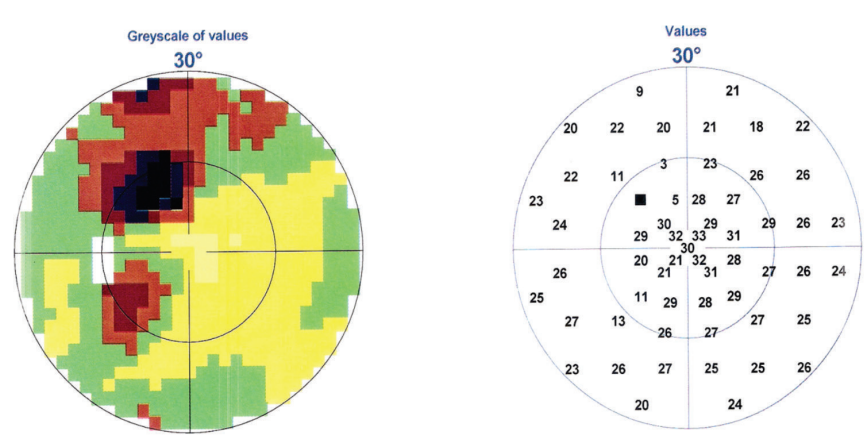

Figure 2: Left eye visual field showing central scotoma

\section{Discussion}

Leishmaniasis is parasitic vector-borne disease caused by a family of obligate intracellular dimorphic protozoa of the genus leishmania $^{(6)}$. In our country, Brazil, the visceral leishmaniasis when associated with malnutrition and co-infections it may be fatal. An increase in transmitions rates related to urbanization has been observed in the past 20 years ${ }^{(7)}$. Visceral leishmaniasis is a worldwide infection including multiples clinical syndromes, increasingly recognized as an opportunistic infection, related with immunosuppression conditions, mainly with HIV infection.

Four clinical syndromes occur:Visceral leishmaniasis usually fatal without treatment, is characterized by hepatosplenomagaly and anemia and is caused mainly by the leshimania donovani; old world cutaneous leishmaniasis; mucotunaneous leishmaniasis and diffuse cutaneous leishmaniasis.

The typical clinical picture of visceral leishmaniasis is fever, constitutional symptoms, hepatosplenomegaly, and pancytopenia $^{(8,9)}$. Hiperpigmentation of skin specially on the hand, feet, abdomen, and forehead, is marked in light skinned patients.

Diagnosis is by finding the intracellular parasite in biopsies or in culture of tissues. A firm diagnosis of visceral leishmaniasis requires demonstration of the parasite in splenic or bone marrow aspirate. Diagnosis can be difficult as parasite identification is not always possible, serological tests have suboptimal sensitivity, and molecular biology techniques, like polymerase chain reaction, are often unavailable in clinical practice. K39 is a no invasive method of diagnosing visceral leishmaniasis under field conditions by testing serum antibody to the leishmanial antigen $\mathrm{K} 39$, the test has high sensitivity and specificity but it remains positive long after treatment (up to 3 years) $)^{(3,7,10)}$.

The differential diagnosis includes leukemia, lymphoma, tuberculosis, histoplasmosis, infectious mononucleosis, brucellosis, malaria, typhoid, and schistosomiasis.

Ocular lesions in visceral leishmaniasis, must frequently the clinical presentation is anterior uveitis either prior to or just after presumed successful treatment of visceral leishmaniais. Uveitis can lead to secondary glaucoma. Retinal hemorrhages is very rare, in a more severe cases these lesions appeared to be "flame-shaped" potentially arising from hemorrhages from arteriolar capillaries of the nerve fiber layer. In all reported cases, there was a correlation with at least moderated-to-severe anemia with thrombocytopenia, a fall in the fibrinogen level in the plasma, or an increase in fibrinolytic activity in the plasma ${ }^{(11)}$. Maude et al. ${ }^{(11)}$ reported perivascular whitening and tortuous vessels in patients with visceral leishmaniasis, which would be consistent with the presence of vasculopathy, possibly causing 
focal ischaemia. These lesions resolved after the treatment for leishmaniasis and improvement of the anemia and thrombocytopenia ${ }^{(11.12)}$. Other ocular lesions include subacute focal retinitis, nerve fiber layer infarcts that resolve spontaneously, central retinal vein thrombosis, papillitis, and keratitis, they also regress after the treatment ${ }^{(1,4,5,7,13)}$.

Treatment of choice is pentavalente antimonial compounds and multiple drug therapy especially combined stibogluconate and allopurinol is also recommended. Anfotericin-B is used in severe cases.

Ocular lesions may be missed, because it has been almost very difficult to be differentiated among the others types of ocular disease caused by others pathogens. The ophthalmologist ought to be aware of the lesions caused by the leishmaniasis especially in endemic areas on account of the early recognition of the ocular lesions may help in the diagnosis and management.

\section{RefERENCES}

1. Montero JA, Ruiz-Moreno JM, Sanchis E. Intraretinal hemorrhage associated with leishmaniasis. Ophthalmic Surg Lasers Imaging. 2003; 34(3):212-14.

2. Meyers AJMW, Klassen-Fischer MK, Neafie RC. Visceral leishmaniasis. In: Topics on the pathology of protozoan and invasive arthropod diseases. Bethesda: Uniformed Services University of the Health Sciences; 2011. p. 1-11.

3. Zadeh MM, Manshai K, Shaddel M, Oormazdi H. Ocular leishmaniasis review article. Iran J Ophthalmol. 2006;12(3):1-5.

4. Nimir AR, Saliem A, Ibrahim IA. Ophthalmic parasitosis: a review article. Interdiscip Perspect Infect Dis. 2012;2012:587402.

5. Kanavi MR, Soheilian M. Other vector-borne parasitic infections. In: Foster CS. Diagnosis and Treatment of uveitis. 2nd ed. New Delhi: Jaypee-Highlights; 2013.
6. Petersen CA, Greenlee HW. Neurologic manifestations of leishmania spp. infection. Journal Neuroparasitol. 2011; 2pii:N110401

7. Gontijo CMF Melo MN. Visceral leishmaniasis in Brazil: current status, challenges and prospects. Rev Bras Epidemiol. 2004;7(3):338-49.

8. Carvalho S, Tavares S, Cunha M, Pinto JP, Guimarães F. Leishmaniose visceral - a propósito de um caso clínico com hemorragias retinianas. Rev Soc Port Med Intern. 2012;19(1):79-86.

9. Tierney LM, McPhee SJ, Papadakis MA. Current medical diagnosis e treatment. 45th ed. New York: McGraw Hil; 2006.

10. Goswami RP, Bairaqi B, Kundu PK. K39 strip test-easy, reliable and cost-effective field diagnosis for visceral leishmaniasis in India. J Assoc Physicians India. 2003;51:759-61.

11. Biswas J, Mani B, Bhende M. Spontaneous resolution of bilateral macular haemorrhage in a patient with Kala-azar. Eye (Lond). $2000 ; 14$ (Pt2):244-6.

12. Maude RJ, Ahmed BU, Rahman AH, Rahman R, Majumder MI, Menezes DB, Abu Sayeed A, Hugues L, MacGillivray TJ, Borooah S, Dhilion B, Dondorp AM, Faiz MA. Retinal changes in visceral leishmaniasis by retinal photography. BMC Infect Dis. 2014;14:527

13. Dechant W, Rees PH, Kager PA, Klauss V, Adala H. Post kala azar uveitis. Br J Ophthalmol. 1980;64(9):680-3.

\section{Corresponding Author}

Ricardo Evangelista Marrocos de Aragão

Rua Osvaldo Cruz, no 2335 - Dionisio Torres

Fortaleza - (CE), Brazil

Tel: 55 (85) 99137-9313

E-mail: ricardomarrocos@yahoo.com 